\title{
CHILDREN'S SOCIAL SKILLS THROUGH TRADITIONAL SPORT GAMES IN PRIMARY SCHOOLS
}

\author{
Johan Irmansyah", Ria Lumintuarso, FX. Sugiyanto, Pamuji Sukoco \\ Universitas Negeri Yogyakarta, Indonesia \\ *e-mail: joevoley@gmail.com
}

\begin{abstract}
Traditional society still perceives that physical education is ineffective in shaping children's character and that physical education is still considered as only a playing activity without having significant effects to the development of children's social skill. This research aims to help children shape their social skills through the traditional games provided by physical education teachers with their comprehensive playing activities. The method used in this research was a qualitative approach, by doing some observations and unstructured interviews to teachers and students. The format of the game used in this research was the modification of traditional games called 'Gobak Sodor' which is adapted to the multilateral development of children and the theory of sports education. The result of observation and interview shows that the modified traditional games 'Gobak Sodor' can help children to shape their social skills, such as personal and social responsibility, teamwork, communication and the care of each other in the game. It can be concluded that the social skills of children can not be created instantly. It requires time and continuous learning process. One of the approaches which can be used in forming children's social skills is modified traditional sport games 'Gobak Sodor'.
\end{abstract}

Keywords: children, social skills, games, traditional sport, physical education

\section{KETERAMPILAN SOSIAL ANAK MELALUI PERMAINAN OLAHRAGA TRADISIONAL DI SEKOLAH DASAR}

\begin{abstract}
Abstrak: Pandangan masyarakat tradisional tentang ketidakefektifan pendidikan jasmani dalam membentuk karakter anak dan pendidikan jasmani yang masih dianggap hanya sebagai kegiatan bermain saja tanpa memunyai pengaruh apa pun terhadap perkembangan keterampilan sosial anak. Tujuan penelitian ini untuk membentuk keterampilan sosial anak melalui permainan tradisional yang telah dipersiapkan oleh guru yang mencakup kegiatan bermain secara komprehensif. Metode penelitian menggunakan pendekatan kualitatif dengan melakukan observasi dan wawancara tidak terstruktur kepada guru pendidikan jasmani dan peserta didik. Bentuk permainan yang digunakan dalam penelitian ini adalah modifikasi permainan traditional 'Gobak Sodor' yang disesuaikan dengan perkembangan multilateral anak dan teori pendidikan olahraga. Hasil observasi dan wawancara menunjukkan bahwa modifikasi permainan traditional 'Gobak Sodor' mampu membentuk keterampilan sosial anak seperti tanggung jawab pribadi dan sosial, kerja sama dalam permainan, dan komunikasi dan kepedulian antarsesama dalam permainan. Lewat penelitian ini dapat disimpulkan bahwa pembentukan keterampilan sosial anak tidak bisa dilakukan dengan instan, butuh waktu, dan proses pembelajaran yang berkesinambungan dalam mencapai tujuan tersebut. Salah satu pendekatan yang bisa digunakan dalam membentuk keterampilan sosial anak adalah model permainan olahraga traditional 'Gobak Sodor'.
\end{abstract}

\section{Kata Kunci: anak-anak, keterampilan sosial, permainan, olahraga tradisional, pendidikan jasmani}

\section{PENDAHULUAN}

Pendidikan sejatinya merupakan proses pembentukan karakter individu mulai dari sedini mungkin. Dengan adanya proses pendidikan yang baik, individu diharapkan bisa menjadi manusia seutuhnya yang memiliki integritas intelektual, berkarakter, dan sehat secara jasmani. Namun, pendidikan saat ini masih dianggap hanya sebagai pembentukan intelektual saja, tanpa memiliki kontribusi pada pengembangan aspek yang lain (Shodiq \& Syamsudin, 2019). Sedangkan kehidupan manusia bukan sekadar pembentukan intelektual, melainkan mencakup berbagai aspek kehidupan, seperti seni, budaya, olahraga, teknologi, musik, kehidupan sosial dan sebagainya. 
Pendidikan moral atau karakter anak yang akan dibentuk melalui aktivitas fisik, kompetensi gerak, permainan, dan olahraga merupakan tugas dan fungsi dariguru pendidikan jasmani (Winarni, 2011), guru diharapkan mampu menyusun model pembelajaran dan mengkondisikan lingkungan sekitar untuk menjadikan anak memiliki keterampilan sosial, baik dengan sesama teman, guru, dan lingkungan. Pendidikan jasmani dalam pengaturan anak usia dini selalu didukung oleh penekanan pada aktivitas bermain (Petrie \& Clarkin-phillips, 2018), ini dipandang sebagai dasar untuk perkembangan anak (pendidikan gerak, perkembangan kognitif, fungsi sosial, dan perkembangan emosional). Varea (2018) menekankan bahwa permainan itu sendiri dapat mendorong perkembangan keterampilan sosial anak, namun, terkadang guru/orang dewasa mengabaikan pentingnya bermain dan berpotensi menghambat peluang bermain bagi anak.

Penelitian Mahabbati, Purwandari, Suharmini, \& Praptiningrum (2019) telah merumuskan skala keterampilan sosial anak berdasarkan kesadaran akan keberagaman di sekolah dasar, dan menunjukkan hasil bahwa terdapat 7 komponen keterampilan sosial yang teridentifikasi, yaitu; (1) kemampuan empati, (2) komunikasi dan interaksi sosial, (3) mengendalikan agresi, (4) sikap terbuka, (5) perilaku membantu, (6) memahami diri, dan (7) perilaku mau belajar. Mchugh (2015) menjelasakan nilai-nilai positif dalam pengembangan keterampilan sosial yang terkait dengan aktivitas fisik dalam pendidikan jasmani, yaitu menumbuhkan kepedulian, meningkatkan harga diri dan kepercayaan diri, menumbuhkan rasa tanggung jawab dan kerja keras, mengembangkan keseluruhan individu, dan menanamkan sikap sportifitas. Mercier (2013) menekankan bahwa pengajaran pendidikan jasmani yang berpusat pada anak secara konsisten akan membantu anak memperoleh keterampilan sosial, seperti; mengembangkan apresiasi antar sesama, meningkatkan harga diri, dan menghargai proses pembelajaran.

Vidoni \& Ulman (2012) juga mengusulkan strategi 'fair play game', dalam pengajaran pendidikan jasmani untuk meningkatkan interaksi sosial yang positif, mengurangi perilaku yang kurang baik, dan mengharuskan anak untuk mengembangkan keterampilan sosial dan bertanggung jawab. Hal ini, menegaskan bahwa pembentukan keterampilan sosial anak telah menjadi agenda penting dalam pengaturan pendidikan jasmani dan olahraga, selain peningkatan keterampilan gerak dasar dan pengajaran teknik olahraga. Oleh karena itu, optimalisasi pembentukan karakter dan keterampilan sosial anak dari sekolah dasar harus menjadi prioritas utama dalam pengajaran pendidikan jasmani (Rismayanthi, 2011).

Meskipun telah dijelaskan melalui kajian literatur dan hasil penelitian tentang pentingnya menumbuhkan keterampilan sosial anak melalui pendidikan jasmani, tidak cukup menutup fakta bahwa masih terdapat stereotip tentang ketidakefektifan pendidikan jasmani dalam membentuk karakter dan keterampilan sosial anak. Hal ini semakin menguatkan pendapat Setiawan (2004) bahwa pendidikan jasmani di Indonesia telah kehilangan identitas sebagai sebuah nilai dan dianggap tidak memiliki entitas dalam pengembangan manusia. Pendidikan jasmani juga akan tetap dilihat sebagai kegiatan bermain saja tanpa mempunyai pengaruh apapun terhadap perkembangan intelektual, karakter, dan keterampilan sosial anak, atau hanya sebagai mata pelajaran tambahan yang bisa dikesampingkan dari mata pelajaran lain (Sutisna, Suherman, Ma'mun, \& Mulyana, 2018). Penelitian Dyson, Cowan, Gordon, \& Powell (2018) juga menunjukkan secara global bahwa terlalu banyak diskusi dan retorika mengenai keadaan pendidikan jasmani di tingkat sekolah dasar, kekurangan bukti mengenai pengaruh kebijakan, dan persepsi guru tentang kurangnya pendidikan jasmani yang berkualitas dalam praktiknya (Fyall, 2017).

Hasil analisis keterlaksanaan pendidikan jasmani dan olahraga di SD/MI di Daerah Istimewa Yogyakarta menunjukkan bahwa kinerja pendidikan jasmani dan olahraga yang terkait dengan aspek beban mengajar, pelaksanaan ekstrakurikuler, pengembangan kompetensi guru dan proses pembelajaran masih belum memuaskan dengan skor 176 masuk kategori $\mathrm{C}$, atau baru mencapai 58,6\% (Rachman, 2011). Rendahnya kinerja pendidikan jasmani dan olahraga, terutama yang terkait dengan pengembangan kompetensi guru dan peoses pembelajaran di sekolah, secara tidak langsung akan berpengaruh terhadap hasil belajar anak, baik pembelajaran gerak dasar, aktivitas kebugaran jasmani, teknik 
olahraga, pengetahuan, dan keterampilan sosial anak. Hasil wawancara peneliti dengan guru pendidikan jasmani di SD Muhammadiyah IV Karangkajen, Daerah istimewa Yogyakarta menjelaskan bahwa guru masih kesulitan dalam mencari dan menyusun model pembelajaran yang efektif untuk menumbuhkan karakter dan keterampilan sosial anak. Guru juga menekankan bahwa masih terdapat peserta didik yang belum bisa bekerjasama dengan teman-teman selama proses pembelajaran, kurangnya kepedulian dengan sesama teman dan lingkungan sekitar, serta anak masih cenderung saling menyalahkan atau kurang bertanggungjawab ketika diberikan tugas oleh guru.

Permasalahan-permasalahan ini, akan semakin menggiring opini masyarakat tentang ketidakbermanfaatan pendidikan jasmani di sekolah, dan menjadikan pendidikan jasmani semakin kehilangan identitas sebagai salah satu mata pelajaran yang berorientasi pada pengembangan manusia seutuhnya (aspek psikomotorik, kognitif, afektif, dan sosial) melalui aktivitas gerakan dan olahraga (UNESCO, 2015). Oleh karena itu, profesi pendidikan jasmani harus memfokuskan kembali upaya pengembangannya, secara lokal, nasional, dan internasional, untuk berkonsentrasi pada perspektif pengembangan agenda strategis dan jangka panjang yang bertujuan menyatukan para pemangku kepentingan utama dalam suatu visi bersama untuk masa depan pendidikan jasmani (Carse \& Keay, 2018).

Berdasarkan permasalahan-permasalahan yang teridentifikasi di atas, maka pendidikan jasmani harus bisa memberikan solusi alternatif dalam upaya peningkatan kualitas manusia yang difokuskan pada peningkatan kesehatan jasmani dan rohani seluruh individu, pemupukan watak/ karakter, dan pembentukan keterampilan sosial anak, serta pengembangan prestasi olahraga yang dapat membangkitkan rasa kebanggaan nasional. Sejatinya, pendidikan jasmani yang berkualitas memungkinkan semua anak untuk menikmati dan berhasil dalam banyak jenis kegiatan fisik (Kirk, 2010), dan mengembangkan berbagai keterampilan dan kemampuan untuk menggunakan taktik, strategi, dan komposisi gagasan untuk mencapai keberhasilan.

Pendidikan jasmani juga merupakan tempat belajar, kesempatan untuk belajar permainan baru, teknik olahraga, dan melakukan aktivitas gerak (Parker, MacPhail, O’Sullivan, Chróinín, \& McEvoy, 2018). Anak-anak melihat bahwa 'melakukan' pendidikan jasmani di sekolah adalah tentang mempelajari bagaimana menjadi aktif secara fisik, terlepas dari kenyataan bahwa anak-anak memahami upaya guru dan pelatih sebagai peluang untuk belajar berlari, melompat, dan melempar dengan lebih baik. Peluang ini sering dipandang sebagai sesuatu yang monoton dan membosankan karena dilakukan secara berulang. Oleh karena itu, guru diharuskan memiliki kreativitas dan inovasi dalam menyusun model pembelajaran yang sesuai dengan tujuan pembelajaran dan karakteristik anak.

Model pembelajaran yang efektif dan sesuai untuk karakteristik anak sekolah dasar adalah model pembelajaran yang menekankan pada aktivitas bermain, bersenang-senang, bergembira, dan persahabatan (Kirk, Macdonald, \& O'Sullivan, 2006), baik itu permainan, teknik olahraga, permainan tradisional, maupun kombinasi dari beberapa permainan dan olahraga. Dalam penelitian ini, akan menggunakan jenis permainan tradisional 'Gobak Sodor', yang diketahui bahwa permainan tradisional 'Gobak Sodor' merupakan salah satu dari 87 permainan tradisional anak yang telah teridentifikasi dari 5 kabupaten/kota di Daerah Istimewa Yogyakarta (Suherman, Dapan, Guntur, \& Muktiani, 2019). Selain itu, penelitian Shinta, Syamsi, \& Haryanto (2019) juga menunjukkan bahwa permainan tradisional 'Gobak Sodor' dapat digunakan sebagai media untuk pembentukan karakter atau keterampilan sosial anak, seperti (1) kerjasama, (2) tanggungjawab, (3) kerja keras, dan (4) kepedulian. Ini dikarenakan dalam permainan tradisional 'Gobak Sodor' terdapat nilai-nilai luhur berupa kearifan lokal yang dapat membentuk karakter atau keterampilan sosial anak. Penggunaan permainan tradisional 'Gobak Sodor' dalam penelitian ini juga didasarkan atas kesadaran untuk terus berupaya dalam mempertahankan identitas budaya bangsa melalui pelestarian dan pengajaran permainan tradisional dalam pendidikan jasmani.

Selain permainan tradisional 'Gobak Sodor', penelitian ini juga didasarkan pada teori 'Perkembangan MultilateralAnak'(Lumintuarso, 2013), dan teori 'Pendidikan Olahraga' (Siedentop, 2002). Perkembangan multilateral anak berfokus pada pengembangan berbagai macam keterampilan gerakan melalui aktivitas 
bermain/permainan beregu dalam pembelajaran pendidikan jasmani. Sedangkan, pendidikan olahraga menekankan pada kedalaman konten pembelajaran yang lebih spesifik dalam mengajarkan teknik gerakan, pemahaman taktis, pengembangan keterampilan pribadi dan sosial, dan pemahaman budaya olahraga (Pill, Penney, \& Swabey, 2012). Penggabungan dan modifikasi antara permainan tradisional 'Gobak Sodor', aktivitas bermain, dan pendidikan olahraga menjadi inovasi yang coba diterapkan peneliti untuk mendapatkan model pembelajaran yang paling tepat dalam menumbuhkan keterampilan sosial anak. Jadi, penelitian ini memiliki tujuan untuk menumbuhkan keterampilan sosial anak melalui permainan tradisional 'Gobak Sodor' yang telah didesain dan dimodifikasi sesuai dengan teori, tujuan pembelajaran, karakteristik permainan, dan karakteristik anak.

\section{METODE}

Penelitian ini menggunakan pendekatan studi kasus dalam penelitian kualitatif yang merupakan strategi penelitian untuk menyelidiki secara cermat suatu program, proses, peristiwa, aktivitas, atau sekelompok individu (Creswell, 2014), serta hal-hal yang menarik bagi peneliti (Gall et al., 2003). Pada tahap ini, peneliti pertama kali melakukan observasi proses pembelajaran dan wawancara terhadap guru tentang kendala/permasalahan yang dihadapi dalam proses pembelajaran.

Subjek penelitian adalah 2 orang guru pendidikan jasmani (satu perempuan dan satu laki-laki) dan 16 anak dari dua kelas berbeda (delapan perempuan dan delapan laki-laki). Pemilihan subjek anak menggunakan teknik purposive sampling, yang menekankan pada penentuan kriteria tertentu dalam pemilihan sampel (Gratton \& Jones, 2004). Penelitian ini difokuskan pada 16 anak yang memiliki keaktifan dalam mengikuti permainan dalam proses pembelajaran, dan rerata umur anak adalah 7-10 tahun karena berada pada kelas rendah (I, II, dan III). Penelitian dilaksanakan di Sekolah Dasar Muhammadiyah IV Karangkajen, Daerah Istimewa Yogyakarta, Indonesia. Sekolah dasar ini merupakan salah satu model sekolah yang masih menekankan nilai-nilai spiritualitas, moral, dan intelektual tanpa mengesampingkan kebebasan anak-anak dalam melakukan permainan.
Teknik pengumpulan data yang digunakan dalampenelitiankualitatifiniadalahobservasidan wawancara tidak terstruktur. Observasi bertujuan untuk menyelidiki permasalahan-permasalahan yang terjadi dalam proses pembelajaran pendidikan jasmani, dan wawancara tidak terstruktur dilakukan untuk merumuskan model pembelajaran/permainan yang sesuai untuk anak, serta pertanyaan-pertanyaan singkat untuk mengetahui respon anak pada saat permainan berlangsung. Instrumen yang digunakan dalam penelitian ini adalah pedoman observasi dan pedoman wawancara yang disusun oleh peneliti berdasarkan kebutuhan pengumpulan data untuk mendukung interpretasi hasil penelitian. Sebelum digunakan, pedoman observasi dan pedoman wawancara diperiksa oleh expert judgment untuk mengarahkan butir-butir pertanyaan/ pernyataan tidak bias atau menyimpang dari tujuan penelitian.

Analisis data dilakukan secara manual menggunakan pendekatan analisis konten yang menjelaskan data secara deskriptif dengan mempertimbangkan hasil pengamatan dan tanggapan dari responden (Creswell, 2014). Interpretasi data yang berfokus pada dampak dari hasil pengamatan dan tujuan yang diinginkan dan kemudian disimpulkan berdasarkan perilaku dan tanggapan responden. Tema-tema yang muncul diidentifikasi dan dikomparasikan melalui proses yang berulang untuk mendapatkan hasil yang kredibel. Proses ini berlangsung sampai pada keseluruhan data tercakup dalam tema atau yang biasa disebut data jenuh. Beberapa hasil pengamatan dan kutipan wawancara yang dianggap paling representatif untuk menjelaskan tema utama, disajikan pada bagian pembahasan.

\section{HASIL DAN PEMBAHASAN \\ Hasil}

Karakteristik utama dalam penelitian ini adalah pengamatan terhadap dampak yang muncul setelah penerapan model permainan olahraga tradisional 'Gobak Sodor' terhadap pembentukan keterampilan sosial anak. Pengamatan dilakukan pada saat proses permainan berlangsung, dan menekankan pada fleksibilitas permainan untuk memberikan anak pengalaman bermain yang menyenangkan. Stimulasi dari peneliti dan guru pendidikan jasmani berupa pertanyaan-pertanyaan yang mengarah pada keterampilan sosial anak pada 
proses permainan juga diberikan, ini dilakukan untuk melihat respon anak secara spontan dalam menjawab pertanyaan, baik secara verbal maupun gerakan.

Temuan penting dari hasil wawancara dan diskusi dengan dua orang guru pendidikan jasmani adalah berupa rumusan permainan tradisional 'Gobak Sodor' yang dimodifikasi berdasar pada perkembangan multilateral anak dan teori pendidikan olahraga. Rumusan tersebut menghasilkan sebuah 'model permainan olahraga tradisional Gobak Sodor'. Setelah itu, tiga tema utama juga diidentifikasi terkait dengan keterampilan sosial anak dari hasil penerapan permainan olahraga traditional 'Gobak Sodor' dan stimulasi pertanyaan pada saat proses permainan berlangsung, yaitu; tanggungjawab, kerjasama, dan komunikasi. Hasil ini relevan dengan penelitian sebelumnya yang menunjukkan bahwa pengembanagan model permainan tradisional mampu membangun karakter anak, seperti kerjasama, kejujuran, percaya diri, dan peduli sesama.

Berdasarkan hasil wawancara dengan guru, menunjukkan bahwa peran guru dalam peningkatan keterampilan sosial anak sangatlah penting, guru sebagai pembimbing, panutan sekaligus contoh yang bisa memberikan dampak langsung terhadap perilaku anak. Ini sesuai dengan ungkapan 'guru' dalam tradisi jawa yang berarti menjadi panutan dan diambil sebagai contoh yang baik. Hasil pengamatan dan stimulasi pertanyaan pada saat proses permainan berlangsung, anak secara tidak langsung sudah menerapkan tanggungjawab mereka dalam permainan, seperti berusaha untuk memenangkan permainan, dan mempertahankan tugas mereka sebaik mungkin dalam menjaga lawan maupun meloloskan diri dari hadangan lawan.

Kerja sama anak dapat dilihat dari minat anak yang lebih suka dengan permainan yang mengarah pada sebuah kompetisi dan kerjasama tim, anak terlihat mampu saling bekerjasama dan saling memotivasi sesama teman, serta menunjukkan kekompakkan dan keseriusan dalam melaksanakan permainan. Dalam hal komunikasi, anak menunjukkan komunikasi aktif antar sesama pemain, walaupun dalam kondisi permainan sedang berlangsung dan sedang melakukan tugas masing-masing. Hal ini juga dikuatkan dengan hasil wawancara dengan guru yang menjelaskan bahwa komunikasi anak di lapangan sudah cukup baik, jarang terjadi perselisihan pendapat antar anak. Jika terjadi perselisihan, anak berusaha memisahkan atau melerai, dan jika sulit diselesaikan sendiri maka anak langsung melaporkan kepada guru. Substansi temuan hasil pengamatan dan wawancara dengan responden, dirumuskan pada Tabel 1.

Penjelasan hasil temuan di atas menunjukkan bahwa guru memiliki peran penting dalam membentuk perilaku maupun keterampilan sosial anak. Guru masih menjadi role model atau panutan bagi anak, terutama di sekolah dasar, sehingga guru harus mampu menjaga dan memberikan contoh perilaku yang baik sesuai dengan norma atau aturan yang berlaku di sekolah dan masyarakat. Selain itu, penyusunan dan pengembangan model pembelajaran/permainan dalam pendidikan jasmani, harus selalu disesuaikan dengan tujuan pembelajaran yang ingin dicapai dan sesuai dengan kebutuhan/karakteristik anak.

\section{Tabel 1. Hasil Interpretasi Wawancara dengan Responden Penelitian}

\begin{tabular}{ll}
\hline Indikator/Tema & Hasil Wawancara \\
\hline Model Permainan & 1. Modifikasi permainan tradisional 'Gobak Sodor'. \\
Olahraga & 2. Integrasi perkembangan multilateral anak dalam permainan tradisional 'Gobak Sodor'. \\
$\begin{array}{l}\text { Tradisional 'Gobak } \\
\text { Sodor' }\end{array}$ & $\begin{array}{l}\text { 3. Internalisasi teori 'Pendidikan Olahraga' yang bertujuan untuk mengembangkan } \\
\text { pemahaman, strategi, keterampilan olahraga, dan menumbuhkan etika dalam olahraga. }\end{array}$ \\
& 4. Hasil modifikasi berupa model permainan olahraga tradisional 'Gobak Sodor'. \\
& 5. Pembentukan keterampilan sosial anak melalui model permainan olahraga tradisional \\
& 'Gobak Sodor'.
\end{tabular}


Tabel 1. (lanjutan)

\begin{tabular}{ll}
\hline Indikator/Tema & Hasil Wawancara \\
\hline Tanggung jawab & $\begin{array}{l}\text { 1. Anak bertanggung jawab secara pribadi dengan tugasnya dalam permainan. } \\
\text { 2. Anak bertanggung jawab secara sosial dengan kelompoknya untuk mempertahankan } \\
\text { garis batas yang sudah menjadi kewajiban untuk menjaganya. }\end{array}$ \\
& $\begin{array}{l}\text { 3. Anak memiliki tanggung jawab dalam mencapai tujuan permainan yaitu kesenangan } \\
\text { dan kemenangan. }\end{array}$ \\
Kerjasama & $\begin{array}{l}\text { 1. Anak melakukan kerjasama dalam menyusun strategi permainan. } \\
\text { 2. Anak menunjukkan kekompakkan dan keseriusan dalam melakukan permainan. }\end{array}$ \\
& 3. Membentuk rasa saling membutuhkan dan ketergantungan antar pemain/tim. \\
Komunikasi & 1. Anak menunjukkan komunikasi aktif antar sesama pemain/tim. \\
& 2. Anak menggunakan komunikasi verbal maupun bahasa tubuh dalam permainan. \\
& 3. Anak menunjukkan kepedulian sesama teman melalui ucapan maupun sikap. \\
4. Anak berkomunikasi dengan guru maupun peneliti dengan bahasa yang santun.
\end{tabular}

\section{Pembahasan}

\section{Model Permainan Olahraga Tradisional 'Gobak Sodor'}

Substansi dari permainan adalah sifatnya yang menekankan pada kesenangan dan kegembiraan anak dalam melakukan permainan (Bailey, 2009), dan tugas guru hanya sebagai fasilitator yang menyediakan seluruh sumber daya pembelajaran yang mendukung proses pembelajaran/permainan (Nelson, Cushion, Potrac, \& Groom, 2014). Oleh karena itu, model permainan seharusnya ditentukan secara khusus oleh para pemain itu sendiri tanpa ada intervensi dari pihak manapun (Varea, 2018). Akan tetapi, karakteristik anak pada usia sekolah dasar, secara umum masih belum bisa memahami problem abstrak atau merumuskan pilihan yang akan diambil (Piaget, 1964), sehingga peran guru pendidikan jasmani menjadi sangat penting dalam menyusun dan menerapkan model permainan yang sesuai dengan karakteristik anak.

Model permainan tradisional dirumuskan oleh peneliti dan dua orang guru pendidikan jasmani yang disesuaikan dengan teori, tujuan pembelajaran, karakteristik permainan, dan karakteristik anak. Pada saat wawancara dengan guru pendidikan jasmani, peneliti memfokuskan pertanyaan tentang model permainan yang sesuai dalam membentuk keterampilan sosial anak. Tanggapan Guru AS, menjelaskan bahwa jenis permainan yang biasanya dipilih adalah permainan yang bersifat beregu dengan tujuan untuk meningkatkan rasa kerjasama, saling menghargai, jujur, dan disiplin guna meningkatkan keterampilan sosial anak. Selaras dengan Guru CG, yang memberikan tanggapan bahwa menerapkan permainan beregu menjadi pilihan dalam membentuk keterampilan sosial anak, seperti kerjasama, tanggungjawab, kepedulian sesama anak, dan kekompakkan dalam permainan.

Pernyataan kedua guru di atas relevan dengan perkembangan multilateral anak yang menekankan pada pengembangan anak secara menyeluruh melalui aktivitas gerak dan permainan, yang meliputi pengembangan keterampilan gerak, kemampuan fisik, dan keterampilan sosial (Lumintuarso, 2013). Aktivitas bermain/permainan juga harus disesuaikan dengan karakteristik pendidikan olahraga, yang meliputi; situasi, lokasi, kompetisi, aktivitas, penilaian, dan penghargaan (Siedentop, 1998). Ini bertujuan untuk meningkatkan minat anak dalam melakukan aktivitas bermain/olahraga, dan menumbuhkan pemahaman tentang etika dalam permainan/ olahraga. Penney, Clarke, Quill, \& Kinchin (2005) juga menekankan bahwa pendidikan olahraga dapat membantu meningkatkan dan memperkuat pembelajaran yang inklusif dalam pendidikan jasmani. Oleh karena itu, penyusunan model permainan harus didasarkan pada perkembangan multilateral anak dan pemahaman tentang aktivitas permainan/olahraga itu sendiri.

Diskusi selanjutnya, peneliti semakin mengarahkan pada model permainan tradisional yang akan coba diterapkan dalam pembelajaran pendidikan jasmani. Peneliti mencoba menawarkan salah satu permainan traditional untuk membentuk keterampilan sosial anak, yaitu permainan tradisional 'Gobak Sodor'. Respon dari guru AS menyiratkan ketertarikan dengan permainan tradisional 'Gobak Sodor', seperti yang dikutip dalam wawancara ("Menarik juga, dulu saya sering memainkannya waktu kecil dengan teman-teman 
dan itu mengasikkan. Saya jadi mengingat masa lalu, waktu belum ada teknologi seperti sekarang, kami bermain bebas di luar rumah"). Pernyataan ini menjelaskan bahwa permainan tradisional 'Gobak Sodor' telah mengakar dan terbentuk dalam pikiran guru yang memiliki pengalaman masa lalu dalam memainkan permainan tradisional 'Gobak Sodor', dan merefleksikan dengan kondisi saat ini tentang adanya pergeseran budaya fisik yang disebabkan oleh perkembangan teknologi (Sinclair \& Thornton, 2018).

Hasil wawancara dengan guru pendidikan jasmani dapat disimpulkan bahwa permainan beregu, internalisasi pendidikan olaharaga, dan permainan traditional 'Gobak Sodor' dapat membentuk keterampilan sosial anak. Relevan dengan hasil penelitian dari Widodo \& Lumintuarso (2017) yang menunjukkan bahwa modifikasi permainan traditional, termasuk 'Gobak Sodor', mampu membangun karakter anak, seperti; kerjasama, kejujuran, percaya diri, dan peduli sesama. Permainan traditional merupakan bentuk aktivitas yang dilakukan sesuai dengan budaya dan kebiasaan yang ada disuatu daerah dengan suasana permainan yang menyenangkan, dan tanpa adanya tekanan atau paksaan apapun (Tsangaridou, Zachopoulou, \& Liukkonen, 2014). Peraturan permainan sesuai dengan kesepakatan bersama dari peserta permainan, dan peran guru hanya memberikan arahan bukan perintah.

Pemilihan permainan traditional ini menurut peneliti dan guru pendidikan jasmani telah memenuhi syarat secara keseluruhan dalam membentuk keterampilan sosial anak (Mchugh, 2015), maupun nilai-nilai moral yang terkandung di dalamnya (Johnson, 2013), serta sebagai bentuk dalam mempertahankan identitas budaya lokal dan konstruksi sosial (Hay \& Macdonald, 2014) yang telah terbentuk di Daerah Istimewa Yogyakarta. Permainan traditional 'Gobak Sodor' diharapkan mampu membentuk keterampilan sosial maupun respon sosial anak (Severinsen, 2014), seperti; tanggung jawab pribadi dan kelompok (Quay \& Peters, 2008), komunikasi sosial, kerjasama antar peserta, dan kepedulian antar sesama (Gano-overway, 2013). Dalam pelaksanaannya di lapangan, bukan hanya permainan traditional 'Gobak Sodor' saja yang menjadi substansi dari permainan, akan tetapi, anak-anak akan diberikan kesempatan sendiri dalam memilih permainan apapun yang mereka inginkan. Kebebasan dalam mengeksplorasi permainan yang ditentukan oleh anak menjadi salah satu stimulus dalam mengajarkan keterampilan sosial anak tersebut (Liu, Karp, \& Davis, 2010).

Berdasarkan penjelasan tentang teoriteori dan hasil penelitian yang mendukung permainan tradisional 'Gobak Sodor', maka, peneliti dan guru pendidikan jasmani sepakat untuk menamakan permainan ini sebagai sebuah "Model Permainan Olahraga Tradisional Gobak Sodor". Pemberian nama ini dilakukan karena, bentuk permainan tradisional 'Gobak Sodor' telah telah mengalami modifikasi sesuai dengan teori, tujuan pembelajaran, karakteristik permainan, dan karakteristik anak. Akan tetapi, hasil modifikasi permainan ini, tidak menghilangkan nilai-nilai yang terkandung dan melekat dalam permainan tradisional itu sendiri. Berikut penjelasan bentuk permainan olahraga traditional 'Gobak Sodor', dapat dilihat pada Gambar 1. di bawah ini:

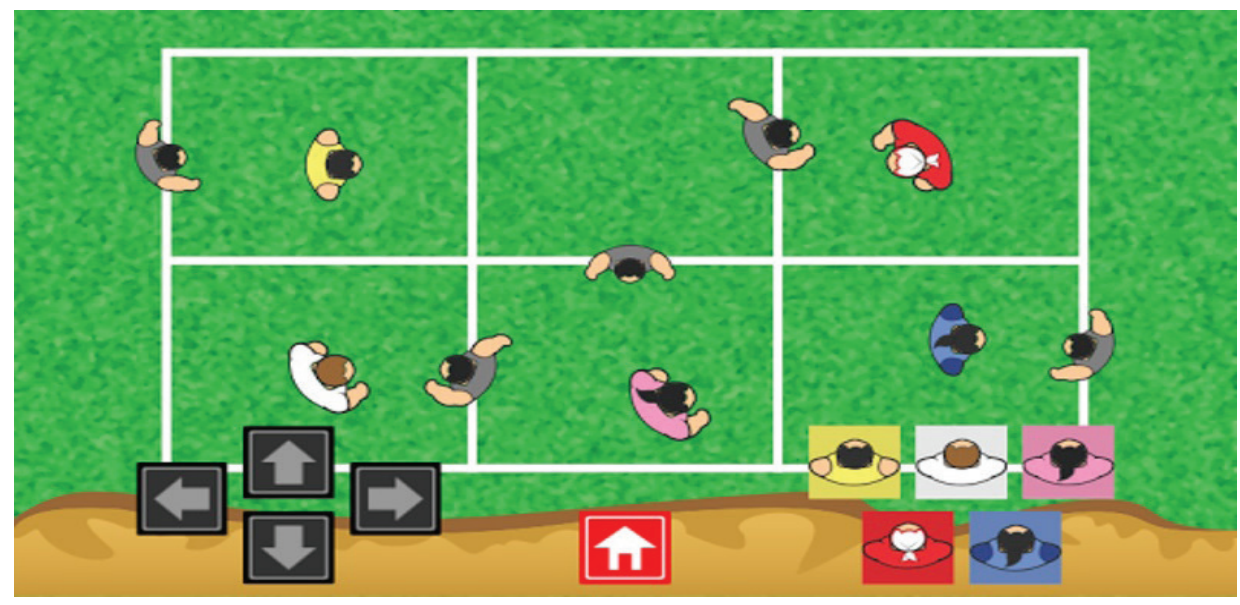

Gambar 1. Traditional Sports Games 'Gobak Sodor' http://www.blue-la-goon-idn.com/galasin-game-gobak-sodor/ 
Peraturan permainan 'Gobak Sodor': Permainan ini merupakan permainan beregu yang terdiri atas dua tim, dengan jumlah pemain 3-5 orang per tim. Permainan ini sangat sederhana karna inti permainannya hanya menghalangi lawan agar tidak melewati garis-garis lapangan dari garis awal sampai akhir secara bolak-balik, dan kemenangan diraih jika anggota tim secara lengkap bisa melewati hadangan dan melakukan proses bolak-balik dalam area lapangan yang telah ditentukan. Untuk modifikasi permainannya, guru pendidikan jasmani menambahkan beberapa aturan seperti mempersiapkan pertanyaan-pertanyaan sederhana pada saat proses permainan berlangsung yang harus dijawab oleh anak. Tujuannya untuk melatih konsentrasi dan emosi yang positif pada saat anak melakukan permainan (Gagnon, 2016). Reward juga diberikan oleh guru sebagai bentuk kepedulian guru dalam mengembangkan keterampilan sosial anak secara keseluruhan (Bennie, Peralta, Gibbons, \& Lubans, 2016). Selanjutnya, anak diberikan kebebasan dalam mengekplorasi gerakan yang dilakukan, dan guru menjelaskan maksud dari gerakan-gerakan tersebut. Ini bertujuan untuk memberikan pengetahuan tentang berbagai macam gerakan, seperti; gerakan lokomotor, non-lokomotor, dan manipulatif (Lumintuarso, 2013).

Permainan traditional 'Gobak Sodor' sering dilakukan di lapangan badminton dengan standar garis-garis yang ada atau bisa membuat sendiri lapangan permainan berbentuk persegi panjang dengan ukuran 9 x $4 \mathrm{~m}$ yang dibagi menjadi 6 bagian. Biasanya batas garis lapangan ditandai dengan kapur. Anggota tim yang mendapat giliran untuk menjaga lapangan, mengambilposisisimasing-masing, yaituanggota tim yang menjaga garis batas horisontal dan garis batas vertikal. Bagi anggota tim yang mendapatkan tugas untuk menjaga garis batas horisontal, harus berusaha untuk menghalangi lawan yang juga berusaha untuk melewati garis batas yang sudah ditentukan sebagai garis batas bebas. Bagi anggota tim yang mendapatkan tugas untuk menjaga garis batas vertikal (umumnya hanya satu orang), maka anak ini mempunyai akses untuk keseluruhan garis batas vertikal yang terletak di tengah lapangan.

Peraturan permainannya juga dimodifikasi oleh guru sesuai dengan teori pendidikan olahraga, yang menekankan iklim kompetisi dalam permainan (Siedentop, 1994; 1998). Ini dilakukan untuk meningkatkan kesungguhan anak dalam permainan, dan diharapkan mampu membentuk tanggungjawab pribadi dan sosial anak, kerjasama tim, komunikasi dalam permainan, dan kepedulian antar sesama. Berdasarkan peraturannya, permainan ini sangat bagus sebagai strategi mengajarkan keterampilan sosial anak (Mercier, 2013), merangsang kinerja keterampilan gerak dasar (Hastie, Valentini, Rudisill, \& Chiviacowsky, 2018), dan meningkatkan kemampuan berpikir anak (Ang \& Penney, 2013).

\section{Tanggung jawab Pribadi dan Sosial}

Salah satu fokus dari permainan olahraga tradisional 'Gobak Sodor' yang akan diterapkan adalah mampu menjadikan anak-anak memiliki tanggung jawab pribadi dan sosial dalam lingkungannya (Pavão, Santos, Wright, \& Gonçalves, 2018). Tanggung jawab pribadi dan sosial dapat dilihat pada saat permainan berlangsung, bagaimana anak bertanggung jawab secara pribadi dengan tugasnya dalam permainan dan bertanggung jawab secara sosial dengan kelompoknya untuk mempertahankan garis batas yang sudah menjadi kewajiban untuk dijaga.

Ketika permainan berlangsung, peneliti mencoba menggangu konsentrasi salah seorang anak yang sedang bertugas menjaga lawan dengan memberikan pertanyaan-pertanyaan yang bersifat klise, seperti 'apakah tidak letih berdiri terus?' atau 'kenapa kamu serius sekali dalam menjaga daerah permainan?'. Respon anak dari pertanyaan-pertanyaan yang peneliti ajukan menunjukkan bahwa anak tidak terlalu merasakan keletihan karena anak sudah larut dalam iklim permainan, anak juga merasa memiliki tanggung jawab untuk memperjuangkan timnya dalam mendapatkan kemenangan. Meskipun, anakanak sedikit kesal karena merasa terganggu konsentrasinya dengan pertanyaan-pertanyaan tersebut, akan tetapi, hasil ini membuktikan bahwa pembentukan iklim permainan yang menantang dapat memberikan anak kepuasan dan kesenangan dalam melakukan permainan (Siedentop, 1998), dan mengajarkan pentingnya tanggungjawab dalam mencapai tujuan bersama/ kelompok (Harvey, Kirk, \& O’Donovan, 2014).

Setelah permainan usai dan anak-anak mulai istirahat, peneliti kembali melakukan 
obrolan dengan beberapa anak-anak. Obrolan ini bertujuan untuk mengetahui respon anak tentang permainan yang sudah dilakukan. Hasil dari respon anak, sebagian besar menggambarkan pengalamannnya masing-masing pada saat melakukan permainan dan menunjukkan rasa senang setelah melakukan permainan. Sebagai contoh, anak GI, dengan kepercayaan diri yang tinggi menyatakan bahwa teman-temannya belum ada yang bisa melewati hadangannya ketika dia berada di posisi penjaga. Berdasarkan pengamatan peneliti, anak GI terlihat lebih aktif melakukan gerakan ketika dalam posisi menghadang lawan, seperti gerakan berpindah, berlari, meregangkan lengan, mengayunkan lengan, atau berbagai gerakan tambahan lainnya (Lumintuarso, 2013).

Sebagai bahan evaluasi, peneliti kembali melakukan wawancara dengan guru untuk memperkuat hasil pengamatan proses permainan dan obrolan dengan anak. Tanggapan dari guru CG tentang keefektifan permainan olahraga tradisional 'Gobak Sodor' dalam membentuk keterampilan sosial anak, sudah dirasa cukup efektif, dikarenakan anak sudah mampu mengikuti permainan dengan perasaan senang dan mampu menunjukkan peran aktif dan tanggungjawabnya dalam bermain dengan teman sebaya. Guru CG juga menambahkan tentang kemampuan anak untuk bergabung/berkontribusi dalam permainan sudah cukup baik, dan tidak memilih-milih teman saat bermain.

Hasil pengamatan pada saat proses permainan, obrolan dengan anak-anak, dan wawancara dengan guru pendidikan jasmani menunjukkan fakta bahwa permainan olahraga traditional 'Gobak Sodor' yang telah dipersiapkan, mampu merangsang aktivitas fisik, keterampilan gerak, dan rasa tanggungjawab anak dalam permainan (Harvey et al., 2014; Lumintuarso, 2013; Siedentop, 1998; Suherman et al., 2019; Widodo \& Lumintuarso, 2017). Anak-anak merasa senang karena mengetahui permainan olahraga traditional 'Gobak Sodor' ini merupakan permainan asli daerahnya, yang merupakan identitas budaya bangsa dengan nilai-nilai moral dan sosial yang terkandung di dalamnya (Jacobs, Knoppers, \& Webb, 2013). Permainan ini juga bisa menjadi alternatif kegiatan yang dimainkan anak di waktu luang, dan diharapkan mampu meminimalisasi dampak dari pesatnya perkembangan teknologi yang mengakibatkan anak-anak lebih memilih memainkan gawai.

\section{Kerja Sama Tim}

Dalam sebuah permainan, dibutuhkan kerjasama tim dalam menyusun strategi sebelum permainan dilakukan atau pada saat proses permainan berlangsung (Turner \& Martinek, 1999). Pendidikan jasmani sebagai sarana dalam membentuk kerjasama anak melalui permainan dan olahraga, harus memiliki pendekatan pembelajaran yang bertujuan untuk meningkatkan rasa soliditas anak-anak dalam bermain dengan satu timnya. Bentuk utama pembelajaran kerjasama dalam pendidikan jasmani adalah dimana anak-anak diberikan tanggungjawab penuh untuk saling membantu dalam memperoleh keterampilan gerak dan sosial (Williams, 2009). Tujuan dalam melakukan kerjasama dalam permainan adalah membentuk rasa saling membutuhkan dan ketergantungan antar pemain, sehingga melalui kerjasama dalam permainan bisa meningkatkan perilaku sosial yang ditunjukkan oleh anak (Tomme \& Wendt, 2015).

Pengamatan dilakukan secara menyeluruh, baik pada saat sebelum permainan, proses permainan, dan sesudah permainan. Sedangkan wawancara dilakukan setelah anak-anak melakukan istirahat dan bersantai di luar lapangan. Hasil pengamatan sebelum permainan dimulai, anak-anak dalam setiap tim melakukan obrolan yang menekankan pada pembagian tugas masing-masing anak dan mendiskusikan strategi/bagaimana cara untuk mendapatkan kemenangan. Sedangkan, pengamatan saat proses permainan berlangsung menggambarkan situasi kekompakkan anak-anak dengan sesama timnya, dan setelah permainan selesai, anak-anak juga memberikan respon melalui wawancara yang dilakukan peneliti. Sebagai contoh, pernyataan dari anak NH dan MR menekankan respon berupa keseriusan dalam melakukan permainan, dan selalu menjaga kekompakkan tim untuk mencapai kemenangan.

Hasil pengamatan dan wawancara di atas menunjukkan bahwa kerjasama antar anak mampu terbentuk melalui permainan olahraga tradisional 'Gobak Sodor'. Oleh karena itu, sesuai dengan penjelasan Bukhari, Efendi, \& Jama (2019) bahwa proses pembelajaran pendidikan jasmani dengan menggunakan aktivitas bermain/permainan 
dapat meningkatkan dan mengembangkan kebugaran fisik, kerjasama, keterampilan, dan sikap kompetitif yang sangat penting sebagai nilai yang harus ditanamkan. Dengan adanya kerjasama maka akan terbentuk tanggungjawab pada setiap anak dalam melakukan tugasnya dengan sebaik mungkin, dan peran guru juga menjadi sangat penting dalam mengembangkan sikap positif anak (Culpan \& Stevens, 2017), kerja sama, dan tanggung jawab terhadap dirinya sendiri atau kelompok. Transfer pengetahuan secara verbal maupun tindakan dari guru, akan menentukan perkembangan psikomotor dan sosial anak, karena pada tahap ini anak memasuki tahap operasional konkrit, dimana secara khusus, pemikiran anak menjadi lebih fleksibel karena mampu menggabungkan berbagai pandangan dan mereduksi menjadi pendekatan yang berbeda (Piaget \& Inhelder, 1969), serta pada tahap ini (secara fisiologis dan anatomi) anak akan terus tumbuh dan berkembang menuju tingkatan orang dewasa (Jarvis, 2006).

Sebagai bahan refleksi, peneliti juga kembali melakukan wawancara dengan guru untuk memperkuat hasil pengamatan dan wawancara dengan anak. Tanggapan dari guru AS menekankan bahwa sebagian anak sudah baik ketika melakukan permainan, ditunjukkan dengan rasa saling menyemangati kepada temantemannya. Anak lebih bertoleransi kepada teman bermainnya, dengan bukti saling menolong apabila ada anak/teman yang terjatuh, dan saling berbagi alat dengan teman. Sebagian besar anak juga ikut berperan aktif dalam permainan, ini terjadi karena guru memberikan kebebasan dan kemandirian kepada anak untuk beraktivitas (Nelson et al., 2014), meskipun semua kegiatan masih tetap dalam pengawasan guru.

\section{Komunikasi dalam Permainan}

Komunikasi merupakan syarat utama dalam melakukan interaksi sosial antar sesama manusia, baik komunikasi verbal maupun nonverbal. Semua aktivitas gerak dan ekspresi yang dilakukan anak-anak dalam permainan menunjukkan komunikasi yang alami. Secara tidak langsung pendidikan jasmani dapat mempromosikan keterampilan sosial dan menjadikan anak-anak yang lebih komunikatif melalui permainan (Vidoni \& Ulman, 2012). Sebagai contoh, pada saat persiapan permainan, terlihat ekspresi anak yang menunjukkan antusias dan kesenangan sebelum permainan dimulai (Wallhead, Garn, \& Vidoni, 2013). Anak-anak begitu responsif mendengarkan penjelasan yang diberikan oleh guru tentang permainan yang dilakukan. Ada anak yang bertanya langsung kepada guru tentang aturan permainannya, ada anak yang menjelaskan kepada temannya bahwa dia sudah melakukan permainan ini di luar lingkugan sekolah, dan ada juga anak yang langsung menawarkan diri menjadi pemain penjaga di lapangan.

Ketika proses permainan berlangsung, komunikasi menjadi salah satu kunci utama untuk memenangkan pertandingan (Varea, 2018). Terjadi komunikasi langsung antar sesama pemain, yang tujuannya untuk meningkatkan rasa percaya diri tim dan menjaga soliditas tim. Kutipan percakapan anak yang diamati peneliti adalah ketika setiap anak saling memotivasi dalam permainan, dan saling mengingatkan untuk terus mempertahankan posisi masingmasing. Komunikasi berupaka gerakan juga teramati dalam permainan, sebagai contoh, salah satu anak memberi aba-aba kepada teman sesama timnya hanya dengan 'gerakan wajah' yang mengindikasikan arah kanan/kiri, dan anggota timnya sudah mengerti maksud dari gerakan tersebut, yaitu segera berlari ke arah kiri/kanan. Satu gerakan wajah saja sudah cukup bagi teman sesama timnya untuk menyadari bahwa tindakan apa yang harus dilakukan.

Dalam menentukan tahap klimaks dalam permainan, dapat diamati ketika setiap anak terfokus pada permainan atau telah menjadi satu dalam permainan (Beni, Fletcher, \& Ní Chróinín, 2017). Tahap ini tercermin dari ekspresi anak yang begitu lepas, seperti tertawa, teriakan, dan bercanda dalam permainan. Sebagai contoh, ketika salah satu tim memenangkan pertandingan, maka tim tersebut akan mengekspresikan kemenangannya dengan teriakan atau tertawa lepas, karena merasa sudah melakukan permainan dengan baik dan mendapatkan kemenangan. Sedangkan, tim yang kalah tidak terlalu kecewa karena sadar tujuan utama dari permainan ini adalah kesenangan dan kegembiraan, selain mencapai tujuan kemenangan.

Teriakan dan tertawa merupakan tanda bahwa semua pemain ikut berkontribusi 
dalam tahap klimaks permainan. Dalam tahap ini, banyak ditemukan sikap dan emosi yang diekspresikan dalam permainan (Gagnon, 2016). Ekspresi teriakan dan tertawa dari anggota tim mengindikasikan bahwa emosi yang diekspresikan berdasar pada sifat kompetitif dalam permainan ini, sehingga setiap tim ingin merasakan kemenangan (Penney et al., 2005). Setelah permainan selesai, peneliti memberikan pertanyaankepadaanak-anak tentang perasaan dan emosi yang diekspresikan saat bermain. Sebagai contoh, pertanyaan seperti apa yang dirasakan ketika permainan berlangsung dan ketika timnya meraih kemenangan. Tanggapan dari anak MR menjelaskan bahwa dalam permainan semuanya bersenang-senang, dan merasa tertantang untuk meraih kemenangan. Hasil pengamatan peneliti juga melihat anak-anak merasa lebih lepas dalam berkomunikasi atau melepaskan kata-kata yang ingin diucapkan, baik secara verbal maupun ekspresi dalam bentuk gerakan.

Hasil di atas menunjukkan komunikasi aktif antar sesama pemain, walaupun dalam kondisi permainan sedang berlangsung dan sedang melakukan tugas masing-masing. Anakanak juga menunjukkan kepedulian untuk tetap saling memotivasi dan mengingatkan, anak-anak lebih menurunkan sikap individualitasnya demi kebaikan kelompok (tim). Interaksi sosial seperti inilah yang diharapkan dalam setiap permainan dan olahraga yang akan dilakukan, anak akan menjadi lebih komunikatif dan peduli terhadap sesama (Wrench \& Garrett, 2015), dan memiliki motivasi tinggi dalam mencapai tujuan (Solmon, 2015).

Sebagai bahan refleksi, peneliti juga kembali melakukan wawancara dengan guru untuk memperkuat hasil pengamatan dan wawancara dengan anak. Tanggapan dari guru AS menjelaskan bahwa komunikasi anak-anak di lapangan sudah cukup baik, jarang terjadi perselisihan pendapat antar anak, serta anak juga menunjukkan ekspresi senang dan gembira dalam melakukan permainan. Jawaban yang diberikan guru ini sesuai dengan pengalamannya selama di lapangan dalam mendidik anak-anak, dan sudah relevan dengan hasil pengamatan yang dilakukan oleh peneliti. Permainan yang dirancang dengan baik, akan membentuk interkasi sosial di dalamnya, dan melalui komunikasi, anak-anak akan saling mengerti dan memahami keinginan antar individu maupun kelompok (Renshaw, Chow, Davids, \& Hammond, 2010).

\section{SIMPULAN}

Pembentukan keterampilan sosial anak tidak bisa dilakukan dengan instan, butuh waktu dan proses pembelajaran yang berkesinambungan dalam mencapai tujuan tersebut. Seperti yang telah dijelaskan, tujuan dari penelitian ini adalah untuk membentuk keterampilan sosial anak melalui permainan olahraga tradisional 'Gobak Sodor' yang telah dirumuskan oleh peneliti dan guru pendidikan jasmani. Hasil implementasi model permainan olahraga tradisional 'Gobak Sodor' terbukti mampu memberikan stimulasi dalam membentuk nilai-nilai karakter, tanggung jawab, komunikasi, kerjasama dan kepedulian dalam permainan. Pemilihan permainan olahraga traditional 'Gobak Sodor' ini, menurut peneliti dan guru pendidikan jasmani telah memenuhi syarat secara keseluruhan dalam membentuk keterampilan sosial anak maupun nilai-nilai moral yang terkandung di dalamnya, serta sebagai bentuk dalam mempertahankan identitas budaya lokal dan konstruksi sosial yang telah terbentuk di Daerah Istimewa Yogyakarta.

Penelitian ini juga menggambarkan kebutuhan mendesak dalam pendidikan jasmani saat ini, yang masih berorientasi hanya pada pengembangan keterampilan gerak saja, serta hasil penelitian ini berupaya untuk membantu menjawab stereotip masyarakat yang masih memandang pendidikan jasmani sebagai mata pelajaran tambahan/tidak terlalu penting dalam pengembangan potensi anak secara keseluruhan. Substansi dari hasil penelitian ini dapat dirumuskan bahwa pendidikan jasmani melalui ragam permainan, pengajaran teknik olahraga, maupun permainan tradisional mampu memberikan sumbangan pengetahuan dan keterampilan kepada anak dalam menjalankan kehidupan sosial di masyarakat. Penelitian di masa depan, diharapkan mampu mengidentifikasi dan mengeksplorasi olahragaolahraga tradisional yang terdapat di daerah masing-masing, sebagai upaya menemukan metode/model terbaik untuk diterapkan dalam pembelajaran pendidikan jasmani sebagai upaya meningkatkan atau membentuk keterampilan gerak dasar, pengetahuan, sikap spiritual, dan sikap/keterampilan sosial anak. 


\section{REFERENCES}

Ang, S. C., \& Penney, D. (2013). Promoting social and emotional learning outcomes in physical education: Insights from a schoolbased research project in Singapore. AsiaPacific Journal of Health, Sport and Physical Education, 4(3), 267-286. doi:1 $0.1080 / 18377122.2013 .836768$.

Bailey, R. (2009). Physical education and sport in schools: A review of benefits and outcomes. In R. Bailey \& D. Kirk (Eds.), The Routledge reader in physical education. London: Routledge, pp. 29-38.

Beni, S., Fletcher, T., \& Ní Chróinín, D. (2017). Meaningful experiences in physical education and youth sport: A review of the literature. Quest, 69(3), 291-312. doi:10.1 080/00336297.2016.1224192.

Bennie, A., Peralta, L., Gibbons, S., \& Lubans, D. (2016). Physical education teachers' perceptions about the effectiveness and acceptability of strategies used to increase relevance and choice for students in physical education classes. AsiaPacific Journal of Teacher Education, 45(3), 302-319. doi:10.1080/135986 6X.2016.1207059.

Bukhari, K., Efendi, Z. M., \& Jama, J. (2019). The development of physical and sport education learning model by using small games. Journal of Physics: Conference Series, 1387(1), 1-5. doi:10.1088/1742$6596 / 1387 / 1 / 012014$

Carse, N., \& Keay, J. (2018). Primary physical education: Shifting perspectives to move forwards. European Physical Education Review, 24(4), 487-502. doi:10.1177/1356336X16688598.

Creswell, J. W. (2014). Educational research: Planning, conducting, and evaluating quantitative and qualitative research (4 ${ }^{\text {th }}$ ed.). Boston, MA: Pearson Education, Inc.

Culpan, I., \& Stevens, S. S. (2017). Olympism, physical education and attitudes and values:
What do graduating teachers in Aotearoa, New Zealand know and understand? Asia-Pacific Journal of Health, Sport and Physical Education, 8(3), 259-272. doi: 18377122.2017 .1345284 .

Dyson, B., Cowan, J., Gordon, B., \& Powell, D. (2018). Physical education in Aotearoa New Zealand primary schools: Teachers' perceptions and policy implications. European Physical Education Review, 24(4), 467-486. doi: $10.1177 / 1356336 \times 17698083$.

Fyall, G. (2017). Graduating physical education student teachers perceptions of a critically oriented HPE curriculum: (Re) constructing constructivist frameworks in PETE. Asia-Pacific Journal of Health, Sport and Physical Education, 8(3), 1-18. doi:10.1080/18377122.2017.1345285.

Gagnon, A. G. (2016). Creating a positive socialemotional climate in your elementary physical education program. Strategies: A Journal for Physical and Sport Educators, 29(3), 21-27. doi:10.1080/08924562.2016 .1159153 .

Gall, M. D., Gall, J. P., \& Borg, W. R. (2003). Educational eesearch: An introduction $\left(7^{\text {th }}\right.$ ed.). United States: Pearson Education, Inc.

Gano-overway, L. A. (2013). Exploring the connections between caring and social behaviors in physical education. Research Quarterly for Exercise and Sport, 84(1), 104-114. doi:10.1080/02701367.2013.76 2322.

Gratton, C., \& Jones, I. (2004). Research methods for sport studies. New York, NY: Routledge.

Harvey, S., Kirk, D., \& O’Donovan, T. M. (2014). Sport education as a pedagogical application for ethical development in physical education and youth sport. Sport, Education and Society, 19(1), 41-62. doi: 10.1080/13573322.2011.624594. 
Hastie, P. A., Valentini, N. C., Rudisill, M. E., \& Chiviacowsky, S. (2018). Children's knowledge of skill cues and the enhancements of motor skill performance. Journal of Physical Education and Sport, 18(3), 1654-1660. doi:10.7752/ jpes.2018.03242.

Hay, P. J., \& Macdonald, D. (2014). Evidence for the social construction of ability in physical education. Sport, Education and Society, 15(1), 1-18. doi:10.1080/13573320903217075.

Jacobs, F., Knoppers, A., \& Webb, L. (2013). Making sense of teaching social and moral skills in physical education. Physical Education and Sport Pedagogy, 18(1), 1-14. doi:10.1080/17408989.2011.62111 8.

Jarvis, M. (2006). Sport psychology: A Student's handbook. New York, NY: Taylor \& Francis e-Library.

Johnson, F. W. (2013). Moral and social values of physical education in the secondary schools. American Physical Education Review, 20(8), 477-487. doi:10.1080/232 67224.1915.10650961.

Kirk, D. (2010). Physical education futures. New York, NY: Routledge Taylor \& Francis Group.

Kirk, D., Macdonald, D., \& O'Sullivan, M. (2006). The handbook of physical education. London, UK: SAGE Publications.

Liu, M., Karp, G. G., \& Davis, D. (2010). Teaching learning-related social skills in kindergarten physical education. Journal of Physical Education, Recreation \& Dance, 81(6), 38-44. doi:10.1080/073030 84.2010.10598490.

Lumintuarso, R. (2013). Pembinaan multilateral bagi atlet pemula. [Multilateral coaching for beginner athletes]. Yogyakarta: UNY Press.
Mahabbati, A., Purwandari, P., Suharmini, T., \& Praptiningrum, N. (2019). Social skill scale based on diversity awareness for elementary school students: Validity and reliability. Proceedings of the International Conference on Special and Inclusive Education (ICSIE 2018), 296, 438-444. doi:10.2991/icsie-18.2019.82.

Mchugh, E. (2015). Going 'beyond the physical': Social skills and physical education. Journal of Physical Education, Recreation \& Dance, 66(4), 18-21. doi:10.1080/0730 3084.1995.10608127.

Mercier, R. (2013). Student-centered physical education- Strategies for teaching social skills. Journal of Physical Education, Recreation \& Dance, 64(5), 60-65. doi:10 .1080/07303084.1993.10609979.

Nelson, L., Cushion, C. J., Potrac, P., \& Groom, R. (2014). Carl Rogers, learning and educational practice: Critical considerations and applications in sports coaching. Sport, Education and Society, 19(5), 513-531. doi:10.1080/13573322.2 012.689256 .

Parker, M., MacPhail, A., O’Sullivan, M., Ní Chróinín, D., \& McEvoy, E. (2018). 'Drawing' conclusions: Irish primary school children's understanding of physical education and physical activity opportunities outside of school. European Physical Education Review, 24(4), 449466. doi:10.1177/1356336X16683898.

Pavão, I., Santos, F., Wright, P. M., \& Gonçalves, F. (2018). Implementing the teaching personal and social responsibility model within preschool education: Strengths, challenges and strategies. Curriculum Studies in Health and Physical Education, 1-20. doi:10.1080/25742981.2018.15524 99.

Penney, D., Clarke, G., Quill, M., \& Kinchin, G. D. (2005). What is sport education and why is it timely to explore it? In D. Penney, G. Clarke, M. Quill, \& G. D. Kinchin (Eds.), 
Sport education in physical education. New York, NY: Routledge Taylor \& Francis Group, pp. pp. 3-22.

Petrie, K., \& Clarkin-phillips, J. (2018). Physical education' in early childhood education: Implications for primary school curricula. European Physical Education Review, 24(4), 503-519. doi:10.1177/1356336X16684642.

Piaget, J. (1964). Part I: Cognitive development in children: Piaget development and learning. Journal of Research in Science Teaching, 2(3), 176-186. doi:10.1002/ tea.3660020306.

Piaget, J., \& Inhelder, B. (1969). The psychology of the child. New York, NY: Basic Books.

Pill, S., Penney, D., \& Swabey, K. (2012). Rethinking sport teaching in physical education: A case study of research based innovation in teacher education. Australian Journal of Teacher Education, 37(8), 118138. doi:10.14221/ajte.2012v37n8.2.

Quay, J., \& Peters, J. (2008). Skills, strategies, sport, and social responsibility: Reconnecting physical education. Journal of Curriculum Studies, 40(5), 601-626. doi:10.1080/00220270801886071.

Rachman, H. A. (2011). Keterlaksanaan pendidikan jasmani dan olahraga di Daerah Istimewa Yogyakarta. [The implementation of physical education and sports in the Special Region of Yogyakarta]. Jurnal Pendidikan Jasmani Indonesia, 8(1), 38-47. doi:10.21831/jpji. v8i1.3482.

Renshaw, I., Chow, J.Y., Davids, K., \& Hammond, J. (2010). A constraints-led perspective to understanding skill acquisition and game play: A basis for integration of motor learning theory and physical education praxis? Physical Education and Sport Pedagogy, 15(2), 117-137. doi:10.1080/17408980902791586.
Rismayanthi,C.(2011).Optimalisasipembentukan karakter dan kedisiplinan siswa sekolah dasar melalui pendidikan jasmani olahraga dan kesehatan. [Optimizing the formation of character and discipline of elementary school students through physical education in sports and health]. Pendidikan Jasmani Indonesia, 8(1), 10-17. doi:10.21831/jpji. v8i1.3478.

Setiawan, C. (2004). Krisis identitas dan legitimasi dalam pendidikan jasmani. [Crisis of identity and legitimacy in physical education]. Jurnal Pendidikan Jasmani Indonesia, 1(1), 1-7. doi:10.21831/jpji.v1i1.112.

Severinsen, G. (2014). Teaching personal and social responsibility to juniors through physical education. Asia-Pacific Journal of Health, Sport and Physical Education, 5(1), 83-100. doi:10.1080/18377122.2014 .867793 .

Shinta, D. K., Syamsi, I., \& Haryanto, H. (2019). Traditional game as a media for character education inclusion elementary school. Proceedings of the International Conference on Special and Inclusive Education (ICSIE 2018), 296, 412-416. doi:10.2991/icsie-18.2019.77.

Shodiq, S. F., \& Syamsudin, S. (2019). Reconstruction of teacher's identity: A socio-anthropological study of the Javanese society. Cakrawala Pendidikan, 38(3), 477-489. doi:10.21831/cp.v38i3.26098.

Siedentop, D. (1994). Sport education: Quality $P E$ through positive sport experiences. Champaign, IL: Human Kinetics.

Siedentop, D. (1998). What is sport education and how does it work? Journal of Physical Education, Recreation \& Dance, 69(4), 1820. doi:10.1080/07303084.1998.10605528.

Siedentop, D. (2002). Sport education: A retrospective. Journal of Teaching in Physical Education, 21(4), 409-418. doi:10.1123/jtpe.21.4.409. 
Sinclair, C., \& Thornton, L. J. (2018). Exploring preservice teachers' conceptions after "living a hybrid curriculum". European Physical Education Review, 24(2), 133151. doi:10.1177/1356336X16669331.

Solmon, M. A. (2015). Optimizing the role of physical education in promoting physical activity: A social-ecological approach. Research Quarterly for Exercise and Sport, 86(4), 329-337. doi:10.1080/02701 367.2015.1091712.

Suherman, W. S., Dapan, Guntur, \& Muktiani, N. R. (2019). Development of traditional children play based instructional model to optimize development of kindergarteners' fundamental motor skill. Cakrawala Pendidikan, 38(2), 356-365. doi:10.21831/ cp.v38i2.25289.

Sutisna, N., Suherman, A., Ma'mun, A., \& Mulyana, M. (2018). Improving active learning time on physical education using movement education model. Proceedings of the $3^{\text {rd International Conference on }}$ Sport Science, Health, and Physical Education (ICSSHPE 2018), 11, 296-298. doi:10.2991/icsshpe-18.2019.84.

Tomme, P. M., \& Wendt, J. C. (2015). Affective teaching: Psycho-social aspects of physical education. Journal of Physical Education, Recreation \& Dance, 64(8), 66-70. doi:10. 1080/07303084.1993.10606812.

Tsangaridou, N., Zachopoulou, E., \& Liukkonen, J. (2014). Developing preschoolers' social skills through cross-cultural physical education intervention. Early Child Development and Care, 184(11), 15501565. doi:10.1080/03004430.2013.865616.

Turner, A., \& Martinek, T. J. (1999). An investigation into teaching games for understanding: Effects on skill, knowledge, and game play. Research Quarterly for Exercise and Sport, 70(3), 286-296. doi:10 $.1080 / 02701367.1999 .10608047$.
UNESCO (United Nations Educational, Scientific and Cultural Organization). (2015). Quality physical education (QPE): Guidelines for policy-maker. France: Author.

Varea, V. (2018). Exploring play in school recess and physical education classes. European Physical Education Review, 24(2), 194208. doi:10.1177/1356336X16679932.

Vidoni, C., \& Ulman, J. D. (2012). The fair play game: Promoting social skills in physical education. Strategies a Journal for Physical and Sport Educators, 25(3), 26-30. doi:10. 1080/08924562.2012.10592149.

Wallhead, T. L., Garn, A. C., \& Vidoni, C. (2013). Sport education and social goals in physical education: Relationships with enjoyment, relatedness, and leisure-time physical activity. Physical Education and Sport Pedagogy, 18(4), 427-441. doi:10.1 080/17408989.2012.690377.

Widodo, P., \& Lumintuarso, R. (2017). Developing models of traditional games to build characters of elementary school students of upper grades. Jurnal Keolahragaan, 5(2), 183-193. doi:10.108 0/17408989.2012.690377.

Williams, E. A. (2009). The contribution of physical education to personal and social development. Pastoral Care in Education, 11(1), 21-25. doi:1080/02643949309470822.

Winarni, S. (2011). Pengembangan karakter dalam olahraga dan pendidikan jasmani. [Character development in sports and physical education]. Cakrawala Pendidikan,30(2), 124-139. doi:10.21831/ cp.v0i2.1460.

Wrench, A., \& Garrett, R. (2015). Emotional connections and caring: Ethical teachers of physical education. Sport, Education and Society, 20(2), 212-228. doi:10.1080 $/ 13573322.2012 .747434$. 